\title{
Relationship between Medium and Large Grade Contractors on Implementing Safety Management in Construction Site
}

\author{
Noor hayatie Yusof, Mohd. Saidin Misnan
}

\begin{abstract}
Construction sectors are familiar with dangerous and exposed to accidents including of minor accidents, ergonomics problem, outdated machinery can cause the breakdown, and lack awareness from employers and employees. However, the occupational can be reduced through the effectiveness of prevention measure by training, good housekeeping, hazard assessment, better personal protective equipment (PPE) and inspection. The main objective of this research is to identify safety management implementation in medium and large grade contractors. A questionnaire was used as the main instrument on a Likert-type scale with a total of 46 returned questionnaire out of the 100 distributed. The respondents of this study are includes project manager, site supervisor, Safety and Health officer (SHO), engineer, clerk, planner, Quantity Surveyor (QS) and architect. The finding of this paper was identified mostly the contractors implement safety before start bidding; and after bidding and before start site work phases. The highest rank of safety activity is implemented in contractor companies is a formal safety incentive program. Furthermore, the results show significant differences on safety management implementation to working experiences and the relationship between contractor companies and safety management implementation. Based on the findings, it can be concluded that the medium and large grade contractors implement safety management properly and good.
\end{abstract}

Index Terms: Construction, Medium and Large Grade Contractors, Safety Management

\section{INTRODUCTION}

The construction industry is heterogeneous and enormously complex because the most construction projects are unique and executed in varied work environment such as involvement of people from various fields and a construction project should be completed within a limited time $[1,2]$. Construction projects can be unpredictable, hence, managing risks in construction projects has been recognized as a very important process in order to achieve project objectives in terms of time, cost, quality, safety and environmental sustainability [3]. To some degree each construction project is unique because no two jobs are ever exactly the same. In its specifics, each structure is tailored to suit its environments, arranged to perform its own particular function, designed to reflect personal taste and preferences [1]. The construction industry includes of wide variety of companies, specialized crafts, and types of projects. The projects vary from single houses to multibillion-ringgit major infrastructure projects [4] such as housing, non- residential building, heavy, highway, utility and industrial [1].

As known, construction industry is regarded as a dangerous industry with various accidents, fatal injuries and risk, while plays an important role to satisfy human development needs [5-10]. According to [11] the civil infrastructures such as roads, sewers, and the built infrastructure of commercial, domestic and public buildings are the basis of any community's health, safety and prosperity. Unfortunately, throughout the history of the construction industry, many fatalities and injuries have occurred in construction site because of poor occupational safety and health culture [4,12], although the roles and regulations of safety and health were provided. The implementation of safety and health management in construction companies is still poor. According to [13], the highest statistic of accident which causes of death in 2018 is construction sector, 81victims; followed by manufacturing, 25 victims. 19 deaths come from no information. The victims of agriculture and finance sectors are 18 and 13 deaths, respectively. 9 deaths come from transport, storage and communication sectors then, public services and statutory authorities of 3 deaths, followed by mining and quarrying sectors with 2 deaths. The lowest deaths of accident are utilities (electricity, gas, and water), wholesale and retail trades, hotel and restaurants of 1 victim, respectively. A disabling in injury or fatal accidents on a construction project will have a significant negative impact on the execution of construction operations [4]. One of the major causes of accidents is unsafe site conditions; basically, this is due to inadequate supervision.

\section{SAFETY AND HEALTH MANAGEMENT}

Safety is one of the most concerned elements in the workplace for the sky-high fatality status around the globe. In most organization, especially high risk industries like construction, safety issues in workplace are the main priority to be tackled [14]. Providing a safe work environment is an ethical matter demonstrating concern for the welfare of anyone working on the project site or passing by the site. According to Keng [15], good safety programs would certainly help in reducing injuries at construction sites and also to minimize construction costs, increase productivity and profitability and more importantly it could save lives of 
workers and consequently contribute positively to the construction industry and the nation as a whole. This is true in many aspects of company operations and is in creating a work safely culture within the company [16]. In addition, safe work site is a function of the physical conditions of the working environment and the behavior or working attitudes of the individual working on the site. Construction company's responsible to provide a safe working including those employed by sub-contractors and to protect the public from harm. The primary factors that motivate safe practices on construction site are humanitarian concern for workers and the public, economic cost of accidents and regulatory requirements for work site safety [4].

The most successful construction project is focusing the outcome of any construction activity in the realization of minimal cost, timely delivery and quality-oriented structure [17]. In addition, the construction companies also have recognized the important of safety management and have developed an effective company safety program that includes new employee orientation, safety training, projectspecific accident prevention plans and job site surveillance. The construction company's also should contains the hazard analysis, hazard prevention, policies and procedures for working safely, employee training, continual workplace inspection and enforcement of company safety policy and procedure. Good safety practice can reduce the cost of doing business because they lead to reduce premiums for workers' compensation and liability insurance and minimize the costs that result from accident and injuries on a job site [4].

In addition, as known as controlling hazards and preventing fatal injuries in construction is a multi-faceted challenge. The first priority and best safety control is a completely remove hazards from construction environments $[18,19]$. However, when complete the hazard removal or control is not possible, training and administrative controls should be applied to promote best safety practices that limit workers exposures to hazards. CIDB, National Institute of Occupational Safety and Health (NIOSH) and other related agencies through government initiatives provide trainings to increase awareness and enhance knowledge on safety among key players in the construction industry [20]. Various types of training have been carried out such as induction, on-job training, competency, seminar, and forum [21]. However, the approach taken to deliver these training sessions remain the same for years i.e. lectures, video demonstrations and hands-on. Apart from competency training, other types of training allocate less attention on hands-on approach [12]. Undoubtedly, safety trainings require more hands-on or practical-based approach, but the nature of hazards itself restricts the implementation of practical-based approach in real-life situation [20].

Referring to Choudry [19], supported that the safety training and communication can set expectations, increase hazard awareness, develop knowledge and skills and reinforce safe building practices. Evidence does indicate that toolbox talks are perceived to be important and may be a component of effective safety programs in construction. In California, construction industry stakeholders identified improving toolbox training as their highest priority intervention area from among several other options [22]. environment for all construction workers on the site,

According to Esmaeili [23], found the studies on components of effective safety programs and identified "project specific training and safety meeting" to be 1 of 12 consensus effective strategies. Other researchers have recommended safety toolbox talks as a flexible method for safety communication and generating discussion [25] because the construction parties have faced with the poor integration and communication [26]. The cooperation among construction parties is one of the important aspects that will contribute to the success of [27] safe environment in workplace.

Table I show the implementation of safety management in medium and large construction company in Taiwan. The determination of safety work rules is the highest of safety management that the company is not implemented $72 \%$, followed by education training is $69 \%$. As known, the education training is important in order to impart safety knowledge and skill to the worker while shaping their safe behaviors to reduce workplace accident rate [28]. Meanwhile, the highest implemented in medium and large company which is hazard notification and the negotiation organization work with $66 \%$ and $72 \%$ respectively. According to [29], concluded that the implementation of safety management is strongly related to the occupational accident occurrence.

The effectiveness of a construction companies safety program often is a key factor in the ability of the company to become prequalified and allowed to submit a proposal of an a project. Project owners (client) do not want unsafe contractors working on their projects, because the owners do not want the negative publicity associated with construction accidents. Unsafe project sites also often lead to citation and resulting fines from state or federal Occupational Safety and Health (OSH) inspections [4].

\section{Table I. Safety Management Work Implementation Performed by Medium and Large Contractor} Companies [29]

\begin{tabular}{|l|l|l|}
\hline Items & $\begin{array}{l}\text { Implemented } \\
(\mathbf{\%})\end{array}$ & $\begin{array}{l}\text { Not } \\
\text { implemented } \\
(\mathbf{\%})\end{array}$ \\
\hline Education training & 31 & 69 \\
\hline Hazard notification work & 66 & 34 \\
\hline $\begin{array}{l}\text { Negotiation organization } \\
\text { work }\end{array}$ & 72 & 28 \\
\hline $\begin{array}{l}\text { Assignment of safety and } \\
\text { health personnel and health }\end{array}$ & 63 & 38 \\
\hline $\begin{array}{l}\text { Safety inspection } \\
\text { autonomous } \\
\text { work }\end{array}$ & 52 \\
\hline $\begin{array}{l}\text { Determination of safety } \\
\text { work rules }\end{array}$ & 72 \\
\hline
\end{tabular}

The Responsibilities and Weaknesses of Safety and Health Compliance by Employers and Employees in Construction Industry

The construction industry comprises many organizations including property developers, architects, engineers, quantity surveyors, accountants, lawyers, and management 
[30]. Everyone on a project, from senior management to the newest employee has responsibility for safety such as Project Manager and Superintendents are responsible for establishing and enforcing safety policies and procedure, providing necessary resources, and effectively communicating $\mathrm{S} \& \mathrm{H}$ information to all people working on the site, both the contractor's employees and the subcontractors. Furthermore, field supervisors implement and enforce those safety policies and procedure as well as conduct hazard analysis, employee training session, accident investigations and safety inspection [4,31]. Supervisors must conduct training to ensure that their workers are knowledgeable of the proper used of all equipment to be employed on the project [4]. The employees are responsible for following established safety procedures, reporting safety hazards and participating in safety training and meetings [4].

Table II clarified for a high percentage of non-compliance exceeding $90 \%$ among employees. The major problem with regards to the safety and health issues at the construction site is the attitude of employees. The behavior of employees is influenced by the safety culture and their attitudes also play a very important part in adopting safe work practice at the workplace. Therefore, safe behavior of the workplace needs to be actively managed. This would suggest that promoting safety education, incentive and enforcement are more approachable and effective way. Referring to Affandi [31], concluded that the level of safety and health compliance between the employees and employers in the Malaysian construction industry is still weak.

Table II. Summary of the Non-Compliance Area Made by Employers [31]

\begin{tabular}{|l|l|l|}
\hline Section & Description & $\begin{array}{l}\text { Non- } \\
\text { Complianc } \\
\text { e (\%) }\end{array}$ \\
\hline 24 & $\begin{array}{l}\text { Duty not to interfere with or } \\
\text { misuse things provided pursuant } \\
\text { to certain provision }\end{array}$ & 72 \\
\hline 25 & $\begin{array}{l}\text { General duties of employees at } \\
\text { work }\end{array}$ & 73 \\
\hline
\end{tabular}

Unfortunately, the current practices of safety and health management in construction industry and the most noncompliance areas done by employers and employees. According to Table III show the current practices of safety and health that compliance in construction industry is slightly poor. The $50 \%$ of non-compliance and above is considered as weaknesses in particular sections. The budget allocation of safety and health manner is slightly poor in current safety and health practice. Additionally, lack of enforcement, monitoring and safety audit on mandatory safety and health requirement due to lack of serious commitment, insufficient workforce and budget allocation are the major factors that lead to the poor site management in $\mathrm{OSH}$ practices in the construction industry. The unsatisfactory $\mathrm{OSH}$ record of the construction industry has always been highlighted. It is because the OSH management system is a neglected area and a function that has not been pursued systematically in the construction industry. It is concluded that safety is an important issue, but many employers do not feel it is vital to the success of companies.
Table III. Summary of the Non-Compliance Area Made by Employers [31]

\begin{tabular}{|l|l|l|}
\hline Section & Description & $\begin{array}{l}\text { Non- } \\
\text { Compliance } \\
(\%)\end{array}$ \\
\hline 15 & $\begin{array}{l}\text { General duties of employers and } \\
\text { self-employed }\end{array}$ & 50 \\
\hline 13 & $\begin{array}{l}\text { Duty to formulate safety and } \\
\text { health policy }\end{array}$ & 65 \\
\hline 17 & $\begin{array}{l}\text { General duties of employers and } \\
\text { self-employed persons to persons } \\
\text { other than their employees }\end{array}$ & 58 \\
\hline 18 & $\begin{array}{l}\text { General duties of occupier of a } \\
\text { place of work to person other their } \\
\text { employees }\end{array}$ & 58 \\
\hline
\end{tabular}

\section{METHODOLOGY}

The study reported in this paper sought to identify the safety management that implemented by large grade contractors (G5-G7) in Malaysian construction industry. This study was used the quantitative approach which is questionnaires as a tool for the data collection. The research is based on 46 returned questionnaire out of the 100 distributed. The content of questionnaires was decided with input from safety expert and literature review and it required to collect safety information from the large grade contractors company were developed.

The questionnaires are divided into three sections. Section A is identified the demographic information of the respondents. This demonstrated among many the experiences of the respondents, improving the credibility and reliability of the information provided by the respondents on the subject. Section B then identified the contractors' company information such as grades of company, types of construction work and number of employees. The last part is Section $\mathrm{C}$ that identified the safety management implemented by large grade contractors in their company. The questions in this section were in the Likert scale of $1-4$, where ' 1 ' is very low and ' 4 ' is very high.

The respondents for this study are includes project manager, safety and health officer, site safety supervisor and others were randomly distribute in large grade contractors company in Malaysia. The data collected from the questionnaire was analyzed by using the descriptive analysis (frequency, percentage and mean), correlation one-way ANOVA and multiple comparison test (Tukey HSD). The one-way ANOVA compared the independent means the responses of safety management implementation in medium and large grade contractors to see if there is a difference among working experience. Then, the Tukey HSD test showed the exact groups with the differences. However, Tukey HSD tests can find the difference between two group means where the one-way ANOVA does find any difference just as ANOVA can be significant but the Tukey HSD is not [32]. The tool of data analyzed was used Statistical Package for the Social Sciences (IBM SPSS Statistics) version 22. 


\section{RESULTS AND DISCUSSIONS}

\section{A. Background Information of Respondents}

Of the 46 respondents, $18(39.1 \%)$ come from G5 company, $2(4.3 \%)$ are from G6 company, and $26(56.5 \%)$ are from G7 company as shown in Fig. 1. The years of work experience of the $19(41.3 \%)$ respondents range from $0-5$ years, 13 (28.3\%) had between 6-10 years of work experience. The respondents with between 11-15 years of works experience were $6(13.0 \%)$ and $8(17.4 \%)$ had over 20 years of work experience in the construction industry. From 46 respondents, ranging of work experience is from 0 5 years to 20 years and above, with a mean of 2.07 and standard deviation of 1.124 . The current designation in the organizations such as 16 project manager, 1 site supervisor, 1 safety and health officer and 28 others (clerk, planner, quantity surveyor, architect, and engineer).

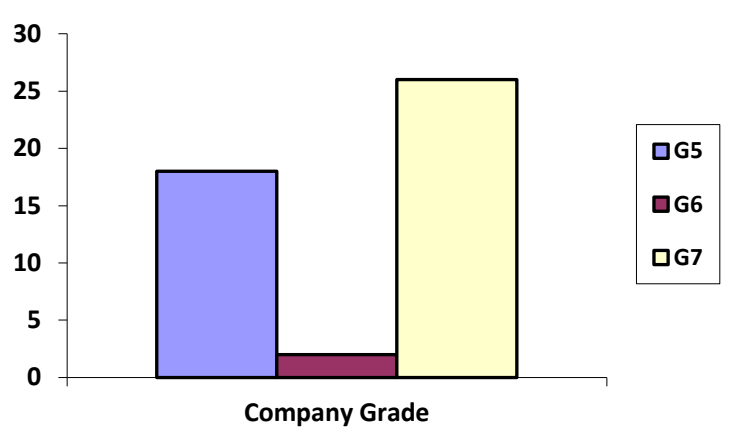

Fig. 1. The Respondents in Medium and Large Grade Contractors

B. Safety Management Implementation in Medium and Large Grade Contractors

According to Table IV show that the phases of implementation safety by medium and large grade contractors in their company. The most frequently of contractors' starts to implement safety for construction project is $23(50 \%)$ namely, before they start to bid the project tender and after bidding and before start the site work, respectively. Secondly, 18 frequencies (39.1\%) where the contractors' implemented safety after they start the site work and 15 frequencies (32.6\%) during the bidding phase. The implementation of safety during the design phases is the lowest frequently, 13 (28.3\%). Majority the medium and large grade contractors are implemented the safety before they start bidding, and after bidding the project tender and before start site work because they need to plan earlier about what safety management and safety equipment they needed for that project and the cost for safety was calculated automatically. The contractors need to put the cost of safety in the project tender. So, if the contractors put the safety cost as a plan, they can implement safety in construction project properly. Consequently, a good safety implementation in construction project can be reduce the accident occurs and it's also can improve the quality of project. Based on that, it can be concluded that the plan of safety earlier is very important in order to identify what kind of project needed for safety management and equipment and also for safety costing. The good and/or specific safety allocation also can improve a good safety implementation by contractors and it can make the construction industry free from hazardous and risky work environment.

The highest ranks in overall of safety implementation during the design phases with a mean score of 1.72 (SD = 0.455). The second mean score ranking of implementation safety during the bidding phases is 1.67 ( $\mathrm{SD}=0.474)$, followed by 1.61 of mean score $(\mathrm{SD}=0.493)$ implementation of safety after the start of site work phases. The lower mean score ranking are implement safety before start bidding, and after bidding the project tender and before start site work phases with a mean score of 1.50 (SD = 0.506), respectively.

Table IV. Safety Implementation Phases

\begin{tabular}{|l|l|l|l|l|}
\hline Phases & $\begin{array}{l}\text { Implemented } \\
(\%)\end{array}$ & Mean & SD & $\begin{array}{l}\text { Ran } \\
\mathrm{k}\end{array}$ \\
\hline $\begin{array}{l}\text { Before start } \\
\text { bidding }\end{array}$ & 50.0 & 1.50 & 0.506 & 4 \\
\hline $\begin{array}{l}\text { After bidding and } \\
\text { before start site } \\
\text { work }\end{array}$ & 50.0 & 1.50 & 0.506 & 4 \\
\hline $\begin{array}{l}\text { During the design } \\
\text { phase }\end{array}$ & 28.3 & 1.72 & 0.455 & 1 \\
\hline $\begin{array}{l}\text { During the } \\
\text { bidding phase }\end{array}$ & 32.6 & 1.67 & 0.474 & 2 \\
\hline $\begin{array}{l}\text { After the start of } \\
\text { site work }\end{array}$ & 39.1 & 1.61 & 0.493 & 3 \\
\hline
\end{tabular}

The safety management was evaluated using 2-point Likert scale. The findings about the safety management that implemented in medium and large grade contractors are summarized in Table V. Based on this table, more than $80 \%$ are implemented safety management such as safety site meeting $(80.4 \%)$, verbal communication $(82.6 \%)$, identify hazards on site before work commenced $(80.4 \%)$, insurance cover for site $(80.4 \%)$, and carrying out site inspection $(84.4 \%)$. Majority the safety inspection in medium and large grade contractors was carried out once a month by authorities such as internal inspector (site manager, site supervisor) and safety person in charge (site safety supervisor, safety and health officer, Department of Occupational Safety and Health (DOSH) and Construction Industry Department Board (CIDB). The safety inspection is important in order to improve the existing and add safety management in construction company. In addition, the toolbox talks were conducted for every day to remind the workers about work in safe conditions and hazardous in workplaces. However, the medium and large grade contractors' also have less than $50 \%$ of safety implementation in their company such as formal safety incentive program $(43.5 \%)$, document of risk assessment $(45.7 \%)$, and document of near misses $(45.7 \%)$. For the rest of safety management that implemented in medium and large grade contractors is more than $50 \%$ and less than $80 \%$. The safety management is important for contractors to plan, check, and act in order to improve the safety performance in construction company.

The lowest ranks in overall of safety management that 
implemented in medium and large grade contractors is carrying out site inspection with a mean score of 1.15 (SD = 0.363 ). The second lowest is verbal communication with mean score of 1.17 (SD $=0.383)$. Meanwhile, safety site meeting, identification of hazard on site before work commence and insurance cover for site show the same mean score of $1.20(\mathrm{SD}=0.401)$, respectively. The toolbox talks show 1.24 of mean score $(\mathrm{SD}=0.431)$, company safety policy and provision of first aid box show the same mean score of 1.26 (std. deviation $=0.444)$, respectively. The mean score of $1.28(\mathrm{SD}=0.455)$ is for safety posters and communicating safety performance to employees was implemented in medium and large grade contractors. The written safety program plan and site inductions of operatives are included in ranking 8 with a mean score of 1.30 (SD = $0.465)$, respectively. The mean score of safety training for supervisor is $1.33(\mathrm{SD}=0.474)$ that implemented in medium and large grade contractors. Showing the safety policy on information board, provide the PPE, and setting safety performance target shows the same mean score by 1.35 (SD $=0.482$ ), respectively. The mean score of ensuring adequate welfare provisions on site is 1.39 ( $\mathrm{SD}=0.493), 1.41$ of mean score $(\mathrm{SD}=0.498)$ of planed safety training for supervisors and/or senior management and planned safety training or operatives (first aid, manual lifting), respectively. The top three ranking of safety management that implemented in medium and large grade contractors is all workers are receive the same orientation with mean score by $1.43(\mathrm{SD}=0.501) .1 .54(\mathrm{SD}=0.504)$ shows the mean score of document of risk assessment and document of near misses, respectively. The highest mean score is 1.57 ( $\mathrm{SD}=$ 0.501) of formal safety incentive program.

Table V. Safety Management Implementation in Medium and Large Grade Contractors

\begin{tabular}{|l|l|l|l|l|}
\hline Items & $\begin{array}{l}\text { Implemented } \\
(\%)\end{array}$ & Mean & SD & Rank \\
\hline $\begin{array}{l}\text { Company safety } \\
\text { policy }\end{array}$ & 73.9 & 1.26 & 0.444 & 10 \\
\hline $\begin{array}{l}\text { Written safety } \\
\text { program plan }\end{array}$ & 69.6 & 1.30 & 0.465 & 8 \\
\hline $\begin{array}{l}\text { Showing the safety } \\
\text { policy on } \\
\text { information board }\end{array}$ & 65.2 & 1.35 & 0.482 & 6 \\
\hline Safety posters & 71.7 & 1.28 & 0.455 & 9 \\
\hline Safety site meeting & 80.4 & 1.20 & 0.401 & 12 \\
\hline $\begin{array}{l}\text { Verbal } \\
\text { communication }\end{array}$ & 82.6 & 1.17 & 0.383 & 13 \\
\hline $\begin{array}{l}\text { Communicating } \\
\text { safety performance } \\
\text { to employees }\end{array}$ & 71.7 & 1.28 & 0.455 & 9 \\
\hline $\begin{array}{l}\text { Formal safety } \\
\text { incentive program }\end{array}$ & 43.5 & 1.57 & 0.501 & 1 \\
\hline $\begin{array}{l}\text { Document of risk } \\
\text { assessment }\end{array}$ & 45.7 & 1.54 & 0.504 & 2 \\
\hline $\begin{array}{l}\text { Identification of } \\
\text { hazards on sites } \\
\text { before work } \\
\text { commenced }\end{array}$ & 80.4 & 1.20 & 0.401 & 12 \\
\hline $\begin{array}{l}\text { Insurance cover for } \\
\text { site }\end{array}$ & 80.4 & 1.26 & 0.444 & 10 \\
\hline $\begin{array}{l}\text { Provision of first } \\
\text { aid box }\end{array}$ & 73.9 & 65.2 & 0.482 & 6 \\
\hline Provide the PPE & 60.9 & 0.493 & 5 \\
\hline $\begin{array}{l}\text { Ensuring adequate } \\
\text { welfare provisions }\end{array}$ & 6.401 & 12 \\
\hline
\end{tabular}

\begin{tabular}{|c|c|c|c|c|}
\hline on site & & & & \\
\hline $\begin{array}{l}\text { Document of near } \\
\text { misses }\end{array}$ & 45.7 & 1.54 & 0.504 & 2 \\
\hline $\begin{array}{l}\text { Site inductions of } \\
\text { operatives }\end{array}$ & 69.9 & 1.30 & 0.465 & 8 \\
\hline $\begin{array}{l}\text { Planed safety } \\
\text { training for } \\
\text { supervisors and/or } \\
\text { senior management }\end{array}$ & 71.7 & 1.41 & 0.498 & 4 \\
\hline Toolbox talks & 76.1 & 1.24 & 0.431 & 11 \\
\hline $\begin{array}{l}\text { Planned safety } \\
\text { training or } \\
\text { operatives- first aid, } \\
\text { manual lifting }\end{array}$ & 58.7 & 1.41 & 0.498 & 4 \\
\hline $\begin{array}{l}\text { Safety training for } \\
\text { supervisor }\end{array}$ & 67.4 & 1.33 & 0.474 & 7 \\
\hline $\begin{array}{l}\text { All workers receive } \\
\text { the same } \\
\text { orientation }\end{array}$ & 56.5 & 1.43 & 0.501 & 3 \\
\hline $\begin{array}{l}\text { Setting safety } \\
\text { performance target }\end{array}$ & 65.2 & 1.35 & 0.482 & 6 \\
\hline $\begin{array}{l}\text { Carrying out site } \\
\text { inspection }\end{array}$ & 84.8 & 1.15 & 0.363 & 14 \\
\hline $\begin{array}{l}\text { Formal safety } \\
\text { inspection/audit }\end{array}$ & 76.1 & 1.24 & 0.431 & 11 \\
\hline
\end{tabular}

C. Statistically Significant Differences on Safety Management Implementation to Working Experience

A one-way between-groups analysis of variance was conducted to explore the impact of work experience on level of optimism, as measured by the Life Orientation Test (LOT). Participants were divided into four groups according to their years of work experience (Group 1: 5 years or less; Group 2: 6-10 years; Group 3: 11-15 years; Group 4: 16-20 years and above). There was a statistically significant difference at the $\mathrm{p}<0.05$ level in LOT scores for the four years of work experience groups; $\mathrm{F}(3,42)=0.36, \mathrm{p}=0.78$. Despite reaching statistical significance, the actual difference in mean scores between the groups was quite small as represented in Table VI. The calculation of effect size using eta squared was 0.03 . Post-hoc comparisons using the Tukey HSD test indicated that the mean score for Group $4(\mathrm{M}=1.43, \mathrm{SD}=0.23)$ was significantly different from Group $2(\mathrm{M}=1.52, \mathrm{SD}=0.15)$. Meanwhile, Table VII demonstrate the mean score for Group 1 and 3 is same with $(\mathrm{M}=1.46, \mathrm{SD}=0.25)$, respectively did not differ significantly from either Group 2 or 4 . As result, the perception on the safety management implementation is the same regardless of working experience.

Table VI. Summary Statistic of ANOVA Test on Safety Management with Difference Working Experience

\begin{tabular}{llclll}
\hline $\begin{array}{l}\text { Description } \\
\text { s }\end{array}$ & $\begin{array}{l}\text { Sum of } \\
\text { Squares }\end{array}$ & $\begin{array}{l}\text { Mean } \\
\text { Square }\end{array}$ & F & Sig. \\
\hline $\begin{array}{l}\text { Between } \\
\text { Groups }\end{array}$ & .051 & 3 & .017 & .363 & .780 \\
$\begin{array}{l}\text { Within } \\
\begin{array}{l}\text { Groups } \\
\text { Total }\end{array}\end{array}$ & 1.984 & 42 & .047 & & \\
\hline
\end{tabular}


Table VII. Statistic of Descriptive Test on Safety Management with Difference Working Experience

\begin{tabular}{lll}
\hline Years of working experience & Mean & Std. deviation \\
\hline 5 years & 1.46 & 0.247 \\
10 years & 1.52 & 0.146 \\
15 years & 1.46 & 0.235 \\
20 years and above & 1.43 & 0.226 \\
Total & 1.47 & 0.213 \\
\hline
\end{tabular}

D. Statistically of Relationship between Contractor Companies and Safety Management Implementation in Medium and Large Grade Contractors

In statistic, the correlation coefficient $r$ measures the strength and direction of a linear relationship between two variables. The strength of correlation, $r=0.5$ and $r=-0.5$. The results of the relationship between contractor companies and safety management were investigated using Pearson product moment correlation coefficient could be presented in Table VIII. The preliminary analyses were performed to ensure no violation of the assumptions of normality, linearity and homoscedasticity. There was a strong, negative correlation between two variables, $\mathrm{r}=-0.545, \mathrm{n}=46, \mathrm{p}<$ 0.0005 , with the most complicated safety management is required in construction industry, the fewer of contractors in order to implement safety in their company.

\section{Table VIII. Relationship between Contractor Companies (Grades) on Safety Management Implementation}

\begin{tabular}{|l|l|l|l|}
\hline Variables & $\mathbf{N}$ & $\begin{array}{l}\text { Correlation } \\
\text { (rho) }\end{array}$ & Sig. \\
\hline $\begin{array}{l}\text { Correlation between contractors } \\
\text { companies on safety } \\
\text { management }\end{array}$ & 46 & -.545 & .000 \\
\hline
\end{tabular}

\section{CONCLUSION}

Adopting a quantitative approach, the safety management implementation in medium and large grade contractors have been identified, assessed, analyzed and presented in this paper. As a consequence, the overall of safety management implementation in medium and large grade contractors is good. However, it still has some lacking in preparing document of risk assessment (SHASSIC, HIRARC, and JSA) and near misses. This weakness is related to the safety implementation phases because during the design phase the contractors and team can identify the hazard, risk and near misses of work. It is supported by [12] that the best time to eliminate hazards from a project is during the initial design phases of feasibility and early concept design. So, the contractors can list down the safety equipment based on the project in order to avoid the over budget, appoint safety personnel if needed and follow the safety rules and regulations properly. The perception of significant differences on safety management implementation is the same regardless of working experiences, because the exposing of safety training and toolbox talk to the new workers. In addition the most complicated safety management is required in construction industry, the fewer of contractors in order to implement safety in their company. For example the requirement to appoint SHO in construction project, the value of project must exceeding
RM20 Million [33] and it only can be appoint for large grade contractors.

Good safety management implementation is important in order to reduce the accident on site and also can remove the hazards from workplace. Some of hazards may not be completely removed and must be controlled through administrative process and also supported external sources like government and third parties. The government and third parties must be support in terms of providing the safety training or safety education for workers.

\section{ACKNOWLEDGMENT}

The authors would like to thank to RADIS project grant, reference no $2521.20 \mathrm{H} 57$ for providing necessary funds to carry out this research.

\section{REFERENCES}

1. S. K. Sears, and G. A. Sears, "Construction project management". Clough, 2008.

2. W. N. Osman, N. S. Amminudin, M. Nasrun, and M. Nawi, "Case Studies of occupational safety and health management in construction site: Contractor perspective". J. Adv. Res. Bus. Management Study, vol. 1, 2017, pp. 9-51.

3. N. Yusof, M. S. Misnan, and S. A. A. Hamid, "Safety activities issues in small grade contractors". 12th South East Asian Technical University Consortium (SEATUC) Symposium, 2018, pp. 81-86.

4. J. Schaufelberger, and K. Y. Lin, "Construction project safety". United State: Wiley, 2014, pp. 288.

5. M. S. Misnan, S. F. Mohamad, Z. M. Yusof, and A Bakri, "Improving construction industry safety standard through audit: Shassic assessment tools". January, 2010.

6. E. Sawacha, S. Naoum, and D. Fong, "Factors affecting safety performance on construction site". Int. J. Proj. Manag., vol. 5, 1999, pp. 15-309.

7. A. Bavafa, A. Mahdiyar, and A. K. Marsono, "Identifying and assessing the critical factors for effective implementation of safety programs in construction projects". Saf. Sci. [Internet]. (June 2017), pp. 47-56. Available from: https://doi.org/10.1016/j.ssci.2018.02.025

8. A. Ayob, A. A. Shaari, M. F. M. Zaki, and M. A. C. Munaaim, "Fatal occupational injuries in the Malaysian construction sector - Causes and accidental agents". Earth Environment Sci., vol. 4, 2018, pp.1-11.

9. A.Dąbrowski, "An investigation and analysis of safety issues in Polish small construction plants". Int. J. Occupational Safety Ergonomic, vol. 24, 2015, pp. 498511.

10. C. M. Segarra, E. B. M Villena, G. M. N. González, B. A. Romero, and S. A. Rodríguez, "Occupational riskprevention diagnosis: A study of construction SMEs in Spain". Safety Sci., vol. 92, 2017 pp. 15-104.

11. O. E. Babatunde, J. M. Yatim, H. Affendi, A. A. Aziz, I M. Yunus, and H. Abdul, "An evaluation of the interfacial bond strength of kenaf fibrous concrete and plain concrete composite"., vol. 1, 2019, pp. 1-6.

12. W. F. W. Azmi, and M. S. Misnan, "Stakeholders attitude towards construction workers in safety and health". J. Eng. Application Sci., vol. 9, 2018.

13. Department Occupational Safety and Health, "Statistik kemalangan pekerjaan mengikut sektor sehingga Oktober 
2018 (Kes Disiasat) [Internet]. (January, 2018). Available from: http://www.dosh.gov.my/index.php/ms/statistikkemalangan-pekerjaan/mengikut-sektor/489statistik/occupational-accidents-statistics

14. A. G. P. Tecka, M. N. A. Asmoni, H. A. Hamidah, M. S. Misnan, J. Y. Leeb, and M. N. Jaafar, "Evaluation criteria of safety and health induction for construction worker (SICW) in Malaysia". J. Teknologi, vol. 73, 2015, pp. 93-7.

15. T. C. Keng, and N. A. Razak, "Case studies on the safety management at construction site". J. Sustain. Sci. Manag., vol. 2, 2014, pp. 90-108.

16. M. S. Misnan, "Model membangunkan budaya keselamatan dalam firma pembinaan di Malaysia". Thesis, Universiti Teknologi Malaysia, 2009.

17. O. S. Williams, R. A. Hamid, and M. S. Misnan, "Causes of building construction related accident in the SouthWestern States of Nigeria"., vol. 1, 2019, pp. 14-22.

18. R. M. Choudhry, D. Fang, S. M. Ahmed, "Safety management in construction: best practices in Hong Kong". J. Prof. Issues Eng. Educ. Pract., vol. 1, 2008, pp. 20-32.

19. R. Olson, A. Varga, A. Cannon, J. Jones, J. I. Gilbert, E. Zoller, "Toolbox talks to prevent construction fatalities : Empirical development and evaluation". Safety Sci., vol. 86, 2016, pp. 122-31.

20. N. I. Mohd, K. N. Ali, S. Bandi, and F. Ismail, "Exploring gamification approach in hazard identification training for Malaysian construction industry"., vol. 1, 2019, pp. 51-7.

21. M. Mansur, and H. S. Peng, "Effectiveness of occupational safety and health training in reducing accidents at work place". Malaysia: Persidangan Kebangsaan Ekonomi Malaysia (PERKEM IV), 2009, pp. 293-324.

22. D. Harrington, B. Materna, J. Vannoy, and P. Scholz, "Conducting effective tailgate trainings". SAGE, J., vol. 3, 2008, pp. 359-69.

23. B. Esmaeili, and M. R. Hallowell, "Diffusion of safety innovations in the construction industry". J. Const. Eng. Manag., vol. 8, 2012, pp. 955-63.

24. J. Hinze, M. Hallowell, and K. Baud, "Constructionsafety best practices and relationships to safety performance". J. Const. Eng. Manag., vol. 10, 2013.

25. J. Hinze, M. Hallowell, and K. Baud, "Constructionsafety best practices and relationships to safety performance". J. Const. Eng. Manag., vol. 10, 2013.

26. M. F. Ashraf, and M. M. Fadhil, "Industrialized Building System ( IBS ) provision in local and international standard form of contracts"., vol. 2, 2018, pp. 67-80.

27. H. L. T. Ariffin, N. I. Mohd, N. E. Mustaffa, S. Bandi, and H. M. C. Cecelia, "Perspectives on issues and the application of the innovative procurement approaches for the Industrialised Building System (IBS)"., vol. 1, 2019 , pp. 39-43.

28. G. A. T. Pui, M. S. Misnan, M. N. Jaafar, J. Lee, and Y. Mei, "A review on the effectiveness of safety training methods for Malaysia". J. Tek., vol. 2, 2015, pp. 9-13.

29. C. Cheng, S. Leu, C. Lin, and C. Fan, "Characteristic analysis of occupational accidents at small construction enterprises". Safety, Sci., vol. 6, 2010, pp. 698-707.

30. S. Rowlinson, "Construction safety management systems". 2004, pp. 453.

31. R. Affandi, and H. T. Chia, "The weaknesses of OSHA 1994 implementation in Malaysian construction industry". UNIMAS, e-journal, Civ. Eng., vol. 2, 2013.

32. N. Umeokafor, "Barriers to construction health and safety self-regulation: a scoping case of Nigeria". Civil Eng. Dimenson, vol. 1, 2017, pp. 44-53.

33. Occupational Safety and Health Act, "Occupational
Safety and Health Act 1994 (Act 514), Malaysia". 1994, pp. $1-250$.

\section{AUTHORS PROFILE}

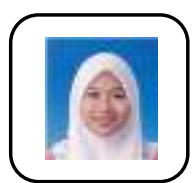

Noorhayatie binti Yusof received B.Sc in Science Construction, Universiti Teknologi Malaysia (2015), M.Sc in Safety Health and Environment, Universit Teknologi Malaysia (2017). She currently doing the Ph.D in Safety, UTM (2017-2020)

AP. Sr. Dr. Mohd. Saidin bin Misnan has a B.Sc in

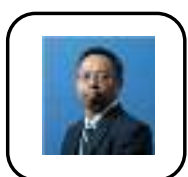
Quantity Surveying (UTM), M.Sc. in Project Management (USM), Ph.D. in Facilities Management, UTM. He is a Senior Lecturer, Department of Quantity Surveying, Universiti Teknologi Malaysia. His current interest is in including Sociology in Construction Industry, Health and Safety, Facilities Management, Project, and Quantity Surveying. 